Europe's Journal of Psychology, 8(1), pp. 49-73, doi:10.5964/ejop.v8i1.298

www.ejop.org

\title{
Media Representations of Youth Violence in Bulgaria
}

\section{Stanislava Stoyanova}

South-West University "Neofit Rilski", Blagoevgrad, Bulgaria

\section{Abstract}

This paper presents a study of media representations of youth violence. The way by which media presents the young generation is a reflection of and influence on the development of identity by youth and society's attitude towards youth. No previous studies have been conducted on this topic in Bulgaria, but the ones carried out in some other countries (including the USA and Australia) revealed an ambiguous image of young people with an important emphasis on violence as a part of youth life. 159 news items concerning young people from September 2010 issues of the Bulgarian newspapers "Telegraph" and "Sega" were coded. $21.4 \%$ of the news items dedicated to young people dealt with violence. Young people as committing an act of violence or as victims of violence were described with some neutral labels indicating their social group membership (gender, ethnic, territorial, etc.) or with some negative labels describing them as criminals. Young people violence in these two Bulgarian newspapers was associated with sexual issues, medical issues and family issues in more than $30 \%$ of the cases, as well as with educational issue in more than $20 \%$ of the news items. The image of young people reflected by the Bulgarian media was not only a negative one. 4/5 of the news items in the newspapers described young people as successful students, sportsmen, politically engaged, doing cultural activities, prepared for business, etc. Adults were advised by the media on how to understand teenagers and how to help young people - having a positive outlook on youth, expressing their love and concern for young people, communicating with them, giving them support (including financial, medical, and educational) by means of the state and different institutions.

Keywords: youth, violence, victims, media representations, deviant behavior

This is an open access article distributed under the terms of the Creative Commons Attribution License (http://creativecommons.org/licenses/by/3.0), which permits unrestricted use, distribution, and reproduction in any medium, provided the original work is properly cited. 
Introduction

Violence is usually considered a severe form of aggression (Moser, 1987). Violence means to make a person suffer physically, affectively and morally (Defrance, 1992) by means of force or putting to shame (Thys, 2003). There are many types of violence - domestic violence, criminal violence, interpersonal violence, proactive violence (violence or the threat of violence to affect outcomes and decisions), reactive violence (post-event protesting against unfavourable outcomes) (Meadow, 2009), etc. There are also many types of aggression - physical aggression, verbal aggression (Smorti, Menesini, \& Smith, 2003), direct aggression (action taken against the source of frustration), indirect aggression (action taken against an object or person other than the instigator), suicide (aggression expressed inwardly, not outwardly) (Allen, 1972). The main distinction between aggression and violence concerns the use of physical force in violence, while aggression does not include obligatory physical force, and the consequences of violence are more severe than those of aggression.

There are different factors influencing aggressive behaviour and violence individual, social (including situational), and cross-cultural. For example, adolescents with aggressive behaviour are not sincere, are emotional instable, and have a low interest for school (Torregrosa, Ingles, \& Garcia-Fernandez, 2011). Female offenders are more rare than male offenders (Olver, Stockdale, \& Wormith, 2009). Male violence drops off at the age of 25 (Dohrn, 1997). The peer factors for violence are need for acceptance, harassment/lack of respect, gossip, etc. (Zimmerman et al., 2004). Japanese students (a collectivistic culture) reveal a greater likelihood of bullying, and a lower likelihood of helping a victim, than Australians students do - an individualistic culture (Nesdale \& Naito, 2005). Research findings also reveal some other factors for violence - even the weather. Political riots and armed attacks occur more frequently in warm countries (van de Vliert, Schwartz, Huismans, Hofstede, \& Daan, 1999). Factors causing aggression and violence are connected and influence together.

This research aims to investigate the image of young people in Bulgarian newspapers (print and online versions) focusing on violent media representations of youth. Social representations are communicated bodies of knowledge that are shared among members of society (McGuire, 1986: 102-103). Media create, change and distribute some social representations (Moscovici \& Markova, 2000) that are a powerful influence on the development of youth identity (Johnson, 2006). The way by which media presents young generation is a reflection of and influence on the society's attitude towards this group. No previous studies have been conducted on this topic in Bulgaria, but those conducted in some other countries (including the 
USA and Australia) revealed an ambiguous image of young people with an important emphasis on violence as a part of youth life (Aitken \& Marchant, 2003; Bolzan, 2003).

\section{Violence in the media and young people}

Through media and video games, violent images are consistently present in children's lives starting from a very young age. Within a typical 1 hour of children's program, an American child is likely to witness one violent act every 4 min (Erwin \& Morton, 2008). From 1973 to 1993, the level of violence in prime-time programming in USA was about five violent acts per hour. In 1994, there were 15 violent scenes in TV media per hour ("Violence and the media", 1999). By the time the typical American child reaches the age of 18, s/he has seen 200000 dramatized acts of violence and 40000 dramatized murders (Clinton, 1999b). Adolescents and parents agree on the adolescent's level of media violence exposure (Kronenberger et al., 2005), about the amount of violence depicted in media, and the children's access to it.

$73 \%$ of American teenagers believed that TV and movies were partly to blame for juvenile crime; $75 \%$ believed that Internet was partly responsible for crimes; $66 \%$ - that music was partly responsible for crimes; $56 \%$ blamed video game violence for crimes ("Violence and the media", 1999). For youth under-18s, violence is more attractive after watching films with violence (Vidal, Clemente \& Espinosa, 2003). Greater number of hours spent watching TV contact sports and violent movies is associated with more favourable attitudes towards military service among men and with more favourable attitudes toward interpersonal violence among women (Brady, 2007).

Media violence (violent television and films, video games, and music) increases the immediate and long-term likelihood of aggressive and violent behaviour. Longitudinal studies link frequent exposure to violent media in childhood with aggression later in life, including physical assaults and spouse abuse. Certain characteristics of viewers (e.g., identification with aggressive characters), social environments (e.g., parental influences), and media content (e.g., attractiveness of the perpetrator) can influence the degree to which media violence affects aggression (Anderson et al., 2003). There are also cathartic effects of some violent programs that could assist in the easing of tension (Ramirez, 2007). Many adolescent boys, especially those with Attention Deficit Hyperactivity Disorder symptoms, use violent video games as a way to release anger. For some teenagers with a learning disability, proficiency at playing violent video games is a source of self-esteem and gives them a more positive standing in their peer groups (Erwin \& Morton, 2008). 
Viewers of media violence tend to feel less sympathetic toward the victims of violence and enjoy more violence portrayed in the media (Fanti, Vanman, Henrich, \& Avraamides, 2009). Children's exposure to daily violence by the entertainment industry and media desensitizes children to violence, develops a sense of callousness towards violence (Clinton, 1999a; Clinton, 1999b), and greater tolerance for aggression (Erwin \& Morton, 2008). The boundary between fantasy and reality violence can become blurred for children (Clinton, 1999b). They are likely to imitate what they see on television thus becoming more indifferent and less empathetic about aggression in the real world. Media violence demonstrates to young children that aggression is an acceptable option for solving problems (Erwin \& Morton, 2008).

\section{Media representations of violent youth}

Media provide evidence and interpretative frames for violence (Meadow, 2009). Through media consumption, males actively construct and maintain impressions of masculinity based on notions of heroism, violence, and "macho" images (Kivel \& Johnson, 2009). Media violence is important at the level of constructing identities.

Concerning representations of young people in newspapers, Australian newspapers portray young Muslim men as violent and dangerous (Mills \& Keddie, 2010). In October 1993 in the USA, over 500 stories in print media related youth and violence ("Children and violence", 1994). American newspapers highlight teenage violence (Aitken \& Marchant, 2003). The topics of youth violence and its causes have been paid increased attention to in newspapers for a long time period. Newspaper reportage about parental use of physical discipline in UK has increased since 1994. Discourse about the use of physical discipline by parents has changed over time from a discourse that focuses on its effectiveness to one that emphasizes children's human rights. The beliefs and attitudes of healthcare professionals and parents about the use of physical discipline may be influenced by media representations (Redman \& Taylor, 2006).

The aim of this paper is to study Bulgarian media representations of youth violence. There are research findings suggesting that, for the period from 1990 to 1998, Bulgarians up to 30 years old were the most aggressive among all age groups (Zografova, 2001). 75.5\% of young people declared that they have committed violence (Kerezova, 2007). These data were collected by means of survey. The hypothesis was that violence among young people would be highlighted in the Bulgarian newspapers, as was the case in the USA (Aitken \& Marchant, 2003) and Australia (Bolzan, 2003), and young people would be presented in media both as 
violent and as victims. This study is focused on a problem that has not been investigated yet. It addresses the role of media in constructing the image of Bulgarian youth.

Method

For the purposes of this research, a content analysis of September 2010 issues of two print Bulgarian daily newspapers ("Sega" and "Telegraph") was carried out. Telegraph is among the cheapest and most distributable Bulgarian daily newspapers with a wide readership. Sega is a daily newspaper focused more on education, politically independent. Both have their print and online versions, but only their print articles for the indicated time period were analysed. 159 news items about young people were coded.

A content analysis matrix was prepared on the basis of the content analysis matrices and results from several previous studies (Anglin, Johnson, Giesbrecht, \& Greenfield, 2000; Bolzan, 2003; Lampman et al., 2002; Ward, 2005). This was a matrix made up of several units of analysis from the content matrices in the studies indicated above. Our content analysis matrix was created to study media representations of the age group from 13 to 25 years old. Several online articles in English about young people were coded by 7 coders from different countries. $81 \%$ agreement was found on how the information should be coded whereas $85 \%$ agreement was found on which information should be coded (Stoyanova et al., 2010).

An excerpt of the content matrix used in this study is included in Appendix. The topics of Law and order, Victims, Deviant behaviour, Alcohol/Drug (item 6 in the Appendix), and the labels Deviants, Victims, Violent, Hooligans, Criminals, and Youth gangs (item 12 in the Appendix) were chosen as indicators of young people's violence. Some units of analyses concerned the salience of the topic of young people violence measured by: number of paragraphs dedicated to this topic, visibility on the pages of the newspapers (which page and number of illustrations), connections with some other topics. Finally, other units of analysis dealt with adults' attitude towards young people.

Results

Salience of Bulgarian media representations of youth violence

The relevance of each topic for the image of young people created and reflected by the media is indicated by its frequency, the length of the articles, their place and format in the newspaper (as means of attracting readers' attention). 
In the total sample of articles, 36 news items were from the September 2010 issues of the newspaper "Sega" and123 news items were from the September 2010 issues of the newspaper "Telegraph", the latter reflecting more the problems and image of young people. The readership of "Telegraph" is wider than of the one of "Sega". The latter consists mainly of the representatives of some state institutions and cultural elite, while the former consists of various social groups.

Table 1. Percentage of the topics related with young people's violence in "Telegraph" and "Sega"

\begin{tabular}{lrr}
\hline Topics & Telegraph" & "Sega" \\
\hline Law and Order & $26.4 \%$ & $2.5 \%$ \\
Deviant behaviour & $23.3 \%$ & $2.5 \%$ \\
Victims & $20.1 \%$ & $2.5 \%$ \\
Alcohol/drug use & $8.2 \%$ & 0 \\
\hline
\end{tabular}

Youth violence probably has medium frequency of presentation in the newspaper "Telegraph" and low frequency in the newspaper "Sega" (see Table 1). The most frequently presented topic was Law and Order, then - Deviant behaviour, then Victims, and the least frequently presented topic was Alcohol/Drug use.

The topics of Law and order, and of Victims did not differ significantly in their frequency (McNemar Test=2.382; $\mathrm{p}=.123$ ), nor did the topics of Law and order, and of Deviant behaviour $(p=.383)$ or the topics of Victims and Deviant behaviour $(p=.424)$. The topics of Law and order (McNemar Test=27.676; $p=.000)$, Deviant behaviour (McNemar Test=19.184; $p=.000$ ) and Victims (McNemar Test=12.410; $p=.000$ ) concerning young people were presented in the selected Bulgarian newspapers significantly more than the topic Alcohol/drug use. Three news items (1.9\%) presented the young people's drug overdose. Six news items (3.8\%) presented alcohol consumption by young people.

In total, 153 paragraphs presented the topic of Deviant behaviour; 152 paragraphs presented the topic of Law and Order; 122 paragraphs presented the topic of Victims; 49 paragraphs presented the topic of Alcohol/drug use (see Table 2). The articles about young people were the longest ones for the topic Deviant behaviour, then Law and Order, -followed by Victims, and the shortest topic was Alcohol/Drug use $\left(\chi^{2}|30|=.916 ; p>.05\right)$, but the difference in length was not significant. 
Table 2. Frequency of the different number of paragraphs presenting youth violence in September 2010 issues of both Bulgarian newspapers "Sega" and "Telegraph"

\begin{tabular}{lrrrr}
\hline $\begin{array}{l}\text { Number of paragraphs } \\
\text { in one news item }\end{array}$ & $\begin{array}{c}\text { Deviant } \\
\text { behaviour }\end{array}$ & $\begin{array}{c}\text { Law and } \\
\text { Order }\end{array}$ & $\begin{array}{c}\text { Victims } \\
\text { Drug use }\end{array}$ & \multicolumn{2}{c}{$\begin{array}{c}\text { Alcohol/ } \\
\text { Drugraph }\end{array}$} \\
\hline paragraphs & 16 & 19 & 12 & 4 \\
2 paragraphs & 6 & 6 & 5 & 0 \\
3 paragraphs & 3 & 5 & 4 & 3 \\
4 paragraphs & 4 & 5 & 7 & 2 \\
5 paragraphs & 3 & 4 & 2 & 1 \\
6 paragraphs & 3 & 3 & 4 & 0 \\
7 paragraphs & 2 & 2 & 1 & 2 \\
9 paragraphs & 1 & 0 & 0 & 1 \\
10 paragraphs & 1 & 0 & 0 & 0 \\
15 paragraphs & 1 & 1 & 0 & 0 \\
19 paragraphs & 1 & 1 & 1 & 0 \\
\hline
\end{tabular}

Table 3. Frequency of the news items on different pages presenting youth violence in September 2010 issues of both Bulgarian newspapers "Sega" and "Telegraph"

\begin{tabular}{lrrrr}
\hline Pages & $\begin{array}{l}\text { Law and } \\
\text { Order }\end{array}$ & $\begin{array}{l}\text { Deviant } \\
\text { behaviour }\end{array}$ & Victims & $\begin{array}{l}\text { Alcohol/ } \\
\text { Drug use }\end{array}$ \\
\hline First page & 1 & 1 & 1 & 1 \\
Other pages & 25 & 24 & 20 & 6 \\
Last page & 20 & 16 & 15 & 6 \\
\hline
\end{tabular}

The most visible topic considering its place in the newspapers was Law and Order, then Deviant behaviour, followed by Victims, and the least visible topic was Alcohol/drug use $\left(\chi^{2}|6|=.387 ; p>.05\right)$. Again this was not a statistically significant trend, similar to the previous findings (see Tables 2 and 3 ).

In total, the topic of Law and Order, and the topic of Victims had 22 illustrations each; the topic of Deviant behaviour had 21 illustrations; the topic of Alcohol/drug use had 6 illustrations $\left.\left(\chi^{2} \mid 12\right)=.001 ; p>.05\right)$. The difference in illustrations among the topics was not significant (see Table 4). 
Table 4. Frequency of the illustrations presenting youth violence in September 2010 issues of both Bulgarian newspapers "Sega" and "Telegraph"

\begin{tabular}{lrrrr}
\hline $\begin{array}{l}\text { Number of } \\
\text { illustrations/photos }\end{array}$ & $\begin{array}{l}\text { Law and } \\
\text { Order }\end{array}$ & Victims & $\begin{array}{l}\text { Deviant } \\
\text { behaviour }\end{array}$ & \multicolumn{2}{c}{$\begin{array}{l}\text { Alcohol/ } \\
\text { Drug use }\end{array}$} \\
\hline 0 illustrations & 33 & 25 & 29 & 8 \\
1 illustration & 8 & 6 & 7 & 4 \\
2 illustrations & 2 & 3 & 2 & 1 \\
3 illustrations & 2 & 1 & 2 & 0 \\
4 illustrations & 1 & 1 & 1 & 0 \\
\hline
\end{tabular}

Law and Order was among the prevalent topics regarding the image of young people since because it was presented in $28.9 \%$ of all news items regarding young people, $58.7 \%$ of the articles regarding this theme were long (more than 1 paragraph), $45.7 \%$ of the articles were on the most visible pages of the newspapers (front and last pages), and $28.3 \%$ of the articles were illustrated.

Victims was also among the prevalent topics regarding the image of young people, because it was presented in $22.6 \%$ of all news items regarding young people, $66.7 \%$ of the articles dealing with this theme were long, $44.4 \%$ of the articles were on the most visible pages of the newspapers, and $30.6 \%$ of the articles were illustrated.

Deviant behaviour was among the prevalent topics regarding the image of young people as well because it was presented in $25.8 \%$ of all news items concerning young people, $61 \%$ of the articles regarding this theme were long, $41.5 \%$ of the articles were on the most visible pages of the newspapers, and $29.3 \%$ of the articles were illustrated.

Alcohol/drug use on the other hand was not among the most prevalent topics regarding the image of young people, because it was presented in $8.2 \%$ of all news items concerning young people; it is to be noted however69.2\% of the articles regarding this theme were long and $53.9 \%$ of the articles were on the most visible pages of the newspapers, and $38.5 \%$ of the articles were illustrated.

Bulgarian media representations of youth violence related it mainly to Law and Order, then relatively equally to Victims, and to Deviant behaviour, and rarely to Alcohol/drug use. 


\section{Content of Bulgarian media representations of youth violence}

Media representations of youth violence include the most frequent labels associated with young people describing their social roles and personal qualities.

Young people were described in the newspapers within the above-mentioned topics (see Table 5 ) using mainly neutral labels $186.4 \%$ within both Law and Order, and Victims; $84.7 \%$ within Deviant behaviour; $85.7 \%$ within Alcohol/Drug use) and rarely negative labels $(13.6 \%$ within both Law and Order, and Victims; $15.3 \%$ within Deviant behaviour; $14.3 \%$ within Alcohol/Drug use). These newspapers strived for objectivity when representing the youth image that is why they gave a lot of details about the social group of membership of a young criminal or a young victim. The newspapers identified young people mainly by means of their social group membership.

Table 5 Frequency of the labels related to youth violence in September 2010 issues of both Bulgarian newspapers "Sega" and "Telegraph"

\begin{tabular}{lrrrr}
\hline $\begin{array}{l}\text { Labels about young } \\
\text { people }\end{array}$ & $\begin{array}{l}\text { Law and } \\
\text { Order }\end{array}$ & $\begin{array}{l}\text { Victims } \\
\text { gender belonging }\end{array}$ & $\begin{array}{l}\text { Deviant } \\
\text { behaviour }\end{array}$ & $\begin{array}{l}\text { Alcohol/ } \\
\text { Drug use }\end{array}$ \\
residents & 24 & 17 & 29 & 9 \\
ethnic belonging & 7 & 5 & 8 & 7 \\
Victims & 4 & 4 & 4 & 0 \\
criminals & 4 & 1 & 3 & 1 \\
hooligans & 3 & 3 & 3 & 1 \\
foreigners & 2 & 1 & 2 & 0 \\
unemployed & 1 & 0 & 0 & 1 \\
citizens & 1 & 0 & 1 & 0 \\
poor persons from poor & 0 & 1 & 1 & 1 \\
families & & & & \\
deviants & 0 & 0 & 1 & 1 \\
minorities & 0 & 0 & 1 & 0 \\
\hline
\end{tabular}

Youth were described as victims of physical assault ( 12 news items); of incidents like the leaking of gas, electric shock, road accident, falling wall, etc. (8 news items); of rape (7 news items); young victims of murder ( 4 news items); of cyber harassment (2 
news items); poverty making young people to become a prostitute or a beggar (2 news items). Two news items dealt with suicide. 32 news items (20.1\%) presented a young people's crimes. The types of crimes committed by youths were physical assault ( 9 news items), theft ( 6 news items), drug use and sale (4 news items), murder (3 news items), rape (3 news items), making illegal sexual movies ( 2 news items), causing damages to property (2 news items), abduction ( 1 news item), telephone terrorism (1 news item), and arson (1 news item).

\section{Media describing society's attitude toward youth}

Different kinds of attitudes toward youth were expressed by the media.

The selected Bulgarian newspapers expressed more negative than neutral and positive adults' attitudes towards young people (see item 9 in Appendix) within the topics of Alcohol/Drug use $\left(\chi^{2}{ }_{|4|}=12.238 ; p=.016 ; 61.6 \%\right.$ negative; $23.1 \%$ positive; $15.3 \%$ neutral), Deviant behaviour $\left(\chi^{2}|4|=56.098 ; p=.000 ; 58.6 \%\right.$ negative; $29.3 \%$ positive; $12.1 \%$ neutral), Law and order $\left(\chi^{2}|4|=33.752 ; \mathrm{p}=.000 ; 50 \%\right.$ negative; $34.8 \%$ positive; $15.2 \%$ neutral), and Victims $\left(\chi^{2}|4|=19.909 ; p=.001 ; 44.5 \%\right.$ negative; $41.6 \%$ positive; $13.9 \%$ neutral). The neutral labels used by media described young people's social membership. The negative attitudes toward youth are expressed in the negative personal qualities attributed by media to young people, and the explicit opinion that young people should be punished for their acts (see Table 6).

Table 6 Number of news items expressing different adults' positions towards young people within the topics of Law and order, Deviant behaviour, Victims and Alcohol/Drug use

\begin{tabular}{lrrrr}
\hline $\begin{array}{l}\text { Adults' position towards } \\
\text { young people }\end{array}$ & $\begin{array}{l}\text { Law and } \\
\text { Order }\end{array}$ & $\begin{array}{r}\text { Victims } \\
\begin{array}{l}\text { adults should punish young } \\
\text { people }\end{array}\end{array}$ & $\begin{array}{l}\text { Deviant } \\
\text { behaviour }\end{array}$ & $\begin{array}{r}\text { Alcohol/ } \\
\text { Drug use }\end{array}$ \\
$\begin{array}{l}\text { adults' concern for young } \\
\text { people }\end{array}$ & 17 & 20 & 15 & 7 \\
$\begin{array}{l}\text { young people need } \\
\text { prevention } \\
\text { adults contribute to the }\end{array}$ & 14 & 13 & 16 & 3 \\
problems of young people* & 8 & 7 & 7 & 2 \\
\hline
\end{tabular}

* dysfunctional homes causing young people to have problems, bad parental behaviour 
Some topics connected to media representations of youth violence Media described a number of aspects of youth life and related them to violence.

The topic of Law and Order concerning young people was related most frequently to the other topics presenting youth violence as Deviant behaviour (for example, young people's crime - 27 news items, or suicide - 2 news items), and Victims (young people as victims in 22 news items and other victims in 2 news items). Some other frequent topics related to Law and Order were Sexual issues, Family issues, Educational issues, and Medical issues (see Figure 1).

Fig. 1. Frequency of the topics related to Law and order concerning young people in September 2010 issues of the Bulgarian newspapers "Sega" and "Telegraph"

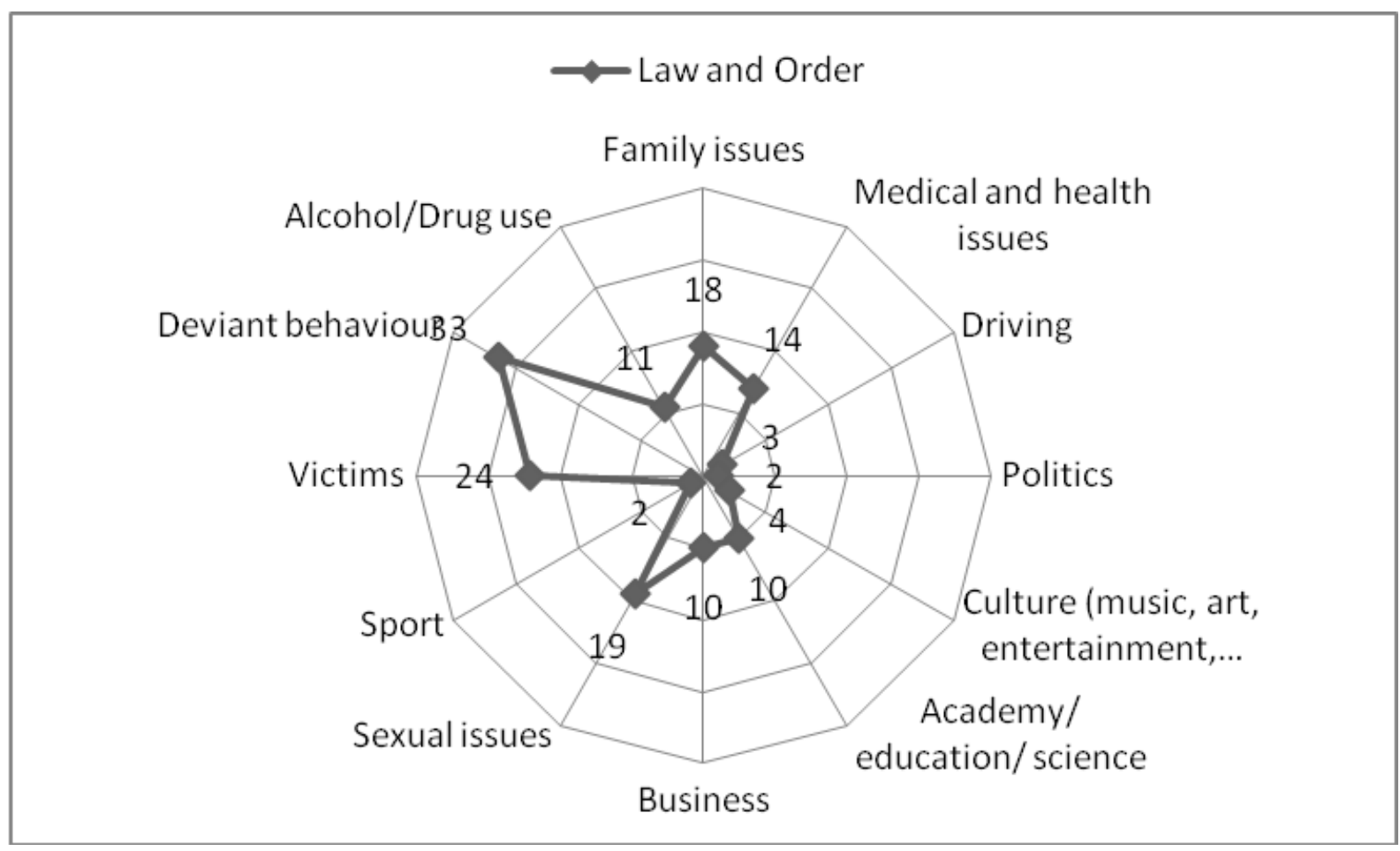

The topic of Victims concerning young people was related most frequently to the other topics presenting youth violence (Deviant behaviour, for example, young people's crime - 17 news items, or suicide - 5 news items; Law and Order). Medical, Family, Sexual, and Educational issues were the other frequent topics related to Victims (see Figure 2). 
Fig. 2. Frequency of the topics related to Victims concerning young people in September 2010 issues of the Bulgarian newspapers "Sega" and "Telegraph"

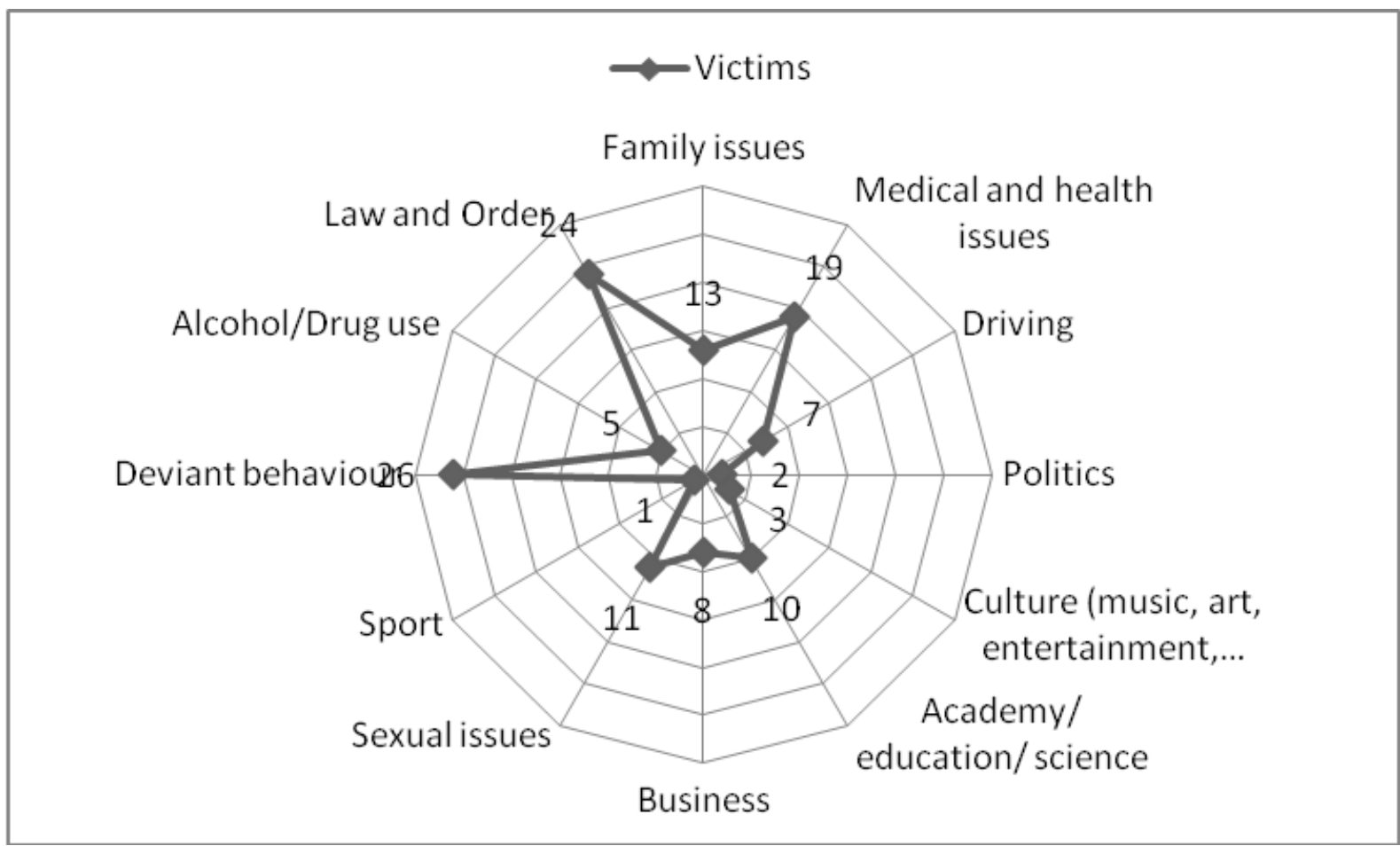

Fig. 3. Frequency of the topics related to Deviant behaviour concerning young people in September 2010 issues of the Bulgarian newspapers "Sega" and "Telegraph"

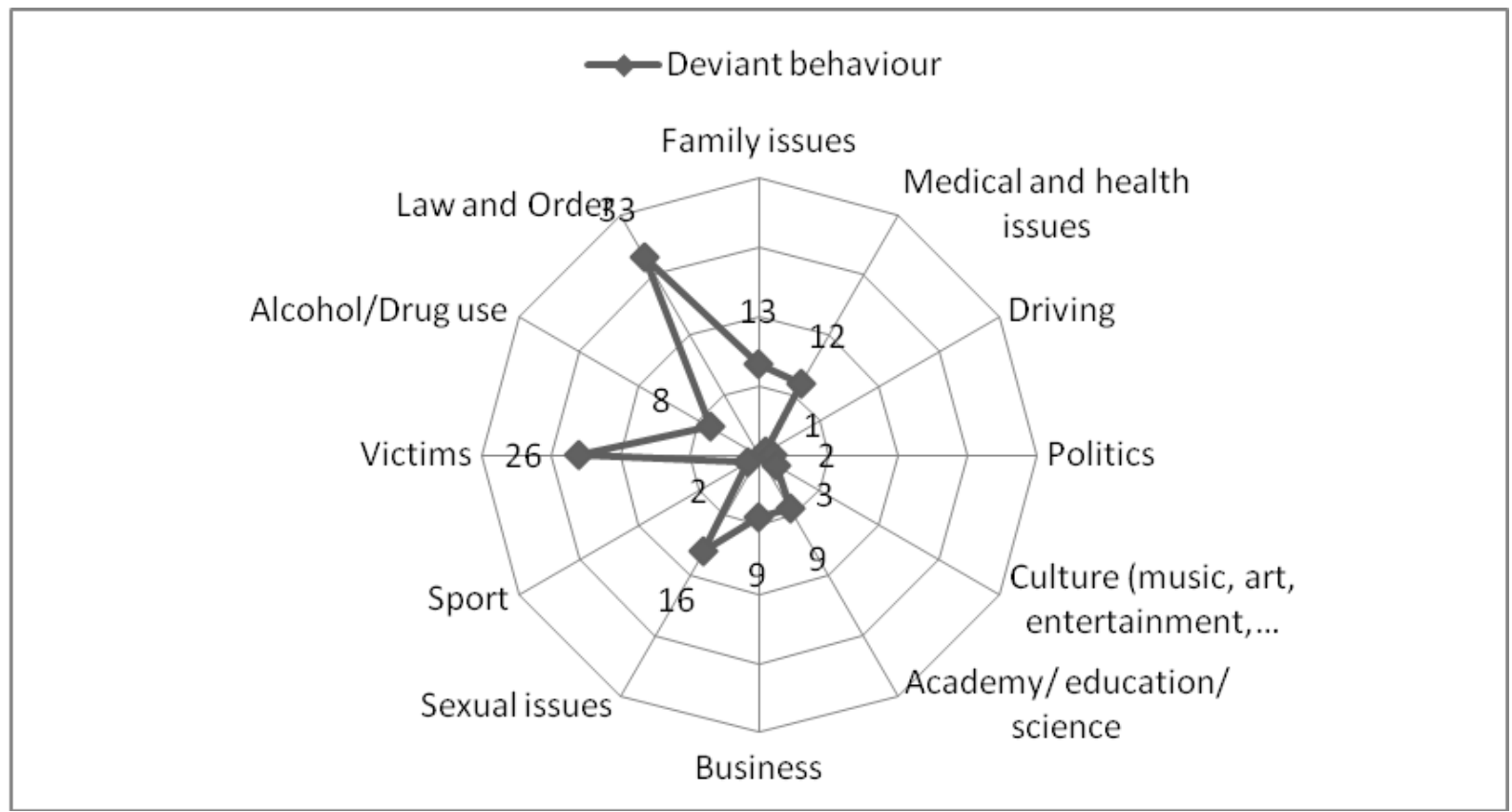


The topic of Deviant behaviour concerning young people was related most frequently to the other topics presenting youth violence as Law and Order, and Victims. Some other frequent topics related to Deviant behaviour were Sexual, Family and Medical issues (see Figure 3).

The topic of Alcohol/Drug use concerning young people was related most frequently to the topics of Law and Order, Deviant behaviour (young people's crime - 9 news items), and Victims. Some other frequent topics related to Alcohol/Drug use were Business issues (for example, young people looking for work - 1 news item, society doesn't offer many job opportunities for young people - 1 news item), Sexual, Family and Medical issues (see Figure 4).

Fig. 4. Frequency of the topics related to Alcohol/Drug use concerning young people in September 2010 issues of the Bulgarian newspapers "Sega" and "Telegraph"

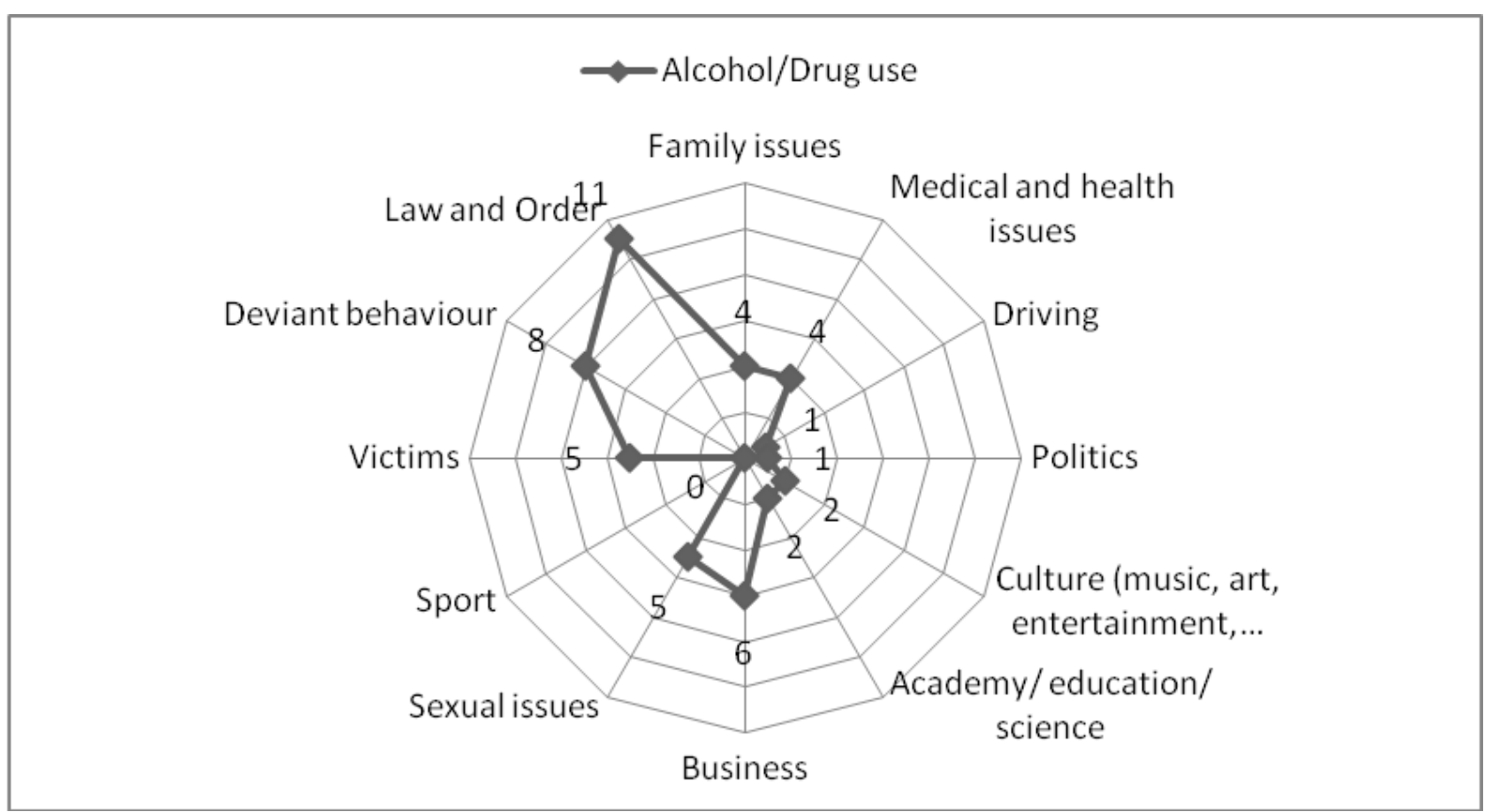

Recommendations by Bulgarian newspapers on how to diminish youth violence

The Bulgarian media gave the following advices to their readers: not to look at young people as criminals (Telegraph, 15.09.2010); conceive a strategy for prevention (Telegraph, 30.09.2010); constantly show that we are interested in and care for those we love (Telegraph, 30.09.2010); justice not to be achieved under 
pressure (Sega, 01.09.2010); schools obtaining poor educational results should be assisted financially in order to be improved the quality of education (Sega, 14.09.2010); people suffering from depression and at risk of suicide should receive some psychological support and medical aid from the doctors and GPs (Telegraph, 10.09.2010); there is a need for a co-ordinating centre that should co-operate with all institutions, the civil sector, teachers, parents, and pupils (Telegraph, 20.09.2010); state exams to exist only at the end of each educational stage, and schools to do the final assessment for the year at the school level (not state level), because the children should not to be burdened unduly (Telegraph, 11.09.2010); the government should work out a policy that would create better conditions for Bulgarian students' professional achievement (Sega, 17.09.2010).

The Bulgarian media and the sources they quoted gave the following advices to parents: parents should communicate much more with their child, every day they should ask their child how s/he is, if s/he has any problems or troubles (Sega, 21.09.2010); personal example is key for any child's development because children will easily break a rule if this rule is not observed by their parents (Sega, 21.09.2010); mothers and fathers should behave as friends in relation to their children (Sega, 01.09.2010).

The Bulgarian media and the sources they quoted gave the following advices to young people: to ask a relative for help or to call a "hot" telephone line (Telegraph, 23.09.2010); to be strong, to work energetically, not to be involved in crimes (Telegraph, 15.09.2010); to use the financial and organizational benefits given to them by the schools and the state (Telegraph, 01.09.2010; Telegraph, 04.09.2010).

These media advices indicate the need for complex educational, economic, political, and cultural interventions in order to prevent and reduce youth violence. Such combined efforts are suggested also by the interconnection between different topics within media news items.

\section{Discussion}

Summarizing the topics Law and order, Deviant behaviour, Victims, and Alcohol/drug use in the total number of 159 news items dedicated to young people that were coded and analysed from the September 2010 issues of the Bulgarian newspapers "Telegraph" and "Sega", young people violence in media was most frequently associated with sexual issues (32.1\%), medical issues (30.8\%), family issues $(30.2 \%)$, and educational issues $(24.5 \%)$. 
Young people violence in media was occasionally associated with business (15.7\%), culture (10.1\%), driving (7.6\%), politics (5.7\%), and sport (3.2\%).

The image of young people reflected by the Bulgarian media was not only a negative one. $4 / 5$ of the publications in the newspapers described young people as successful students $(6 \%)$, sportsmen $(25.2 \%)$, politically engaged $(8.8 \%)$, doing cultural activities (12\%), prepared for business (18\%), etc.

Youth violence was presented moderately in the two Bulgarian newspapers $\left(1 / 5^{\text {th }}\right.$ of all publications for young people related them to violence). $21.4 \%$ of the news items dedicated to young people in the Bulgarian newspapers dealt with violence. Violence was associated with Law and Order, Deviant behaviour, Victims, and Alcohol/Drug use. Alcohol and drug increase the probability of violence (Blumstein, 1995; Zlatanova, 2005, p. 351).

Young people as committing an act of violence or as victims of violence were described with some neutral labels indicating their social group membership (gender, ethnic, territorial, etc.) or with some negative labels identifying them as criminals. Reported violence concerning young people in these Bulgarian media was associated with sexual issues, medical issues and family issues in more than $30 \%$ of the cases. Young people violence in media was related to educational issue in more than $19 \%$ of the news items.

Children and youth are harmed by exposure to sexually explicit material (KimGodwin, Clements, McCuiston, \& Fox, 2009; Kotria, 2007; Olver, Stockdale, \& Wormith, 2009), so connection between violence and sexual issues makes more explicit the negative image of youth in media.

There are a lot of findings supporting the interconnection between family / educational issues and youth violence. Adolescents with aggressive behaviour are more likely to perceive their relationship with their parents as negative (Torregrosa, Ingles, \& Garcia-Fernandez, 2011). Familial context is directly related to school violence (Villarreal-González, Sánchez-Sosa, Veiga, \& Arroyo, 2011). Victims have a negative perception of the school and classroom environment (Martínez Ferrer et al., 2011).

This study pointed to a continuing Bulgarian trend which is characterized by presenting people up to 30 years old as aggressive (Zografova, 2001), as it was the case in the USA (Aitken \& Marchant, 2003) and Australia (Bolzan, 2003), confirming thus the world trends in which young people are either mentioned as arrested for 
crimes (Dohrn, 1997; "Violence and the media", 1999), or as victims of a crime (Sadowski, 1993).

Young people are presented quite equally as both victims and criminals. In 1992 in USA, 5\% of youth ages 10-17 were arrested for a crime (Dohrn, 1997). Juveniles accounted for 1/5 of all violent crime arrests in 1997 in USA ("Violence and the media", 1999). About 10\% of the children ages 10 to 19 in USA were victims of a violent crime (Sadowski, 1993). The crime level in young people however is not higher than the one for adults so the newspaper reporting is skewed. It is obvious that not only young people commit crimes in Bulgaria, but they are the focus of an important part of the newspaper reporting.

The two selected Bulgarian newspapers expressed more negative than neutral and positive adults' attitudes towards young people within the topic of youth violence, in line with the trend in some other countries as well. Young people in Australia were also associated with criminal activity, drug and alcohol use. Media images presented them as not given a lot of opportunities within society (Bolzan, 2003).

There are also some limitations of the study. A more detailed and representative image of Bulgarian youth could have been revealed if a longer time period of media publications concerning young people was studied, or if other newspapers or indeed other varieties of media such as electronic media were considered. Electronic media also influences public opinion about youth nature. In fact, both "Sega" and "Telegraph" have had their online versions including only part of their printed publications, but more readers' comments. The selected media expressed the points of view of their contributing authors. There is a research finding suggesting that more aggressive people attribute more aggressiveness to others (Zografova, 2001), so there could be a bias in the image of violent youth presented by the media sources. The numerous sources of information used in the news items (in total 36 sources for all new items reflecting the topic of Law and order; 33 sources for Victims; 30 for Deviant behaviour; and 11 sources for Alcohol/Drug use) mean striving for objectivity on the part of the media and a more authentic image of young people. The impact of the news items dealing with young people's violence could be significant on the readers, because they confirm an existing stereotype in society and violence is related to multiple aspects of youth life, especially to family life. The stereotype of young people as committing violence is supported by youth since $75.5 \%$ of them declared that they had committed violence in Bulgaria (Kerezova, 2007). 
The selected Bulgarian media presented Bulgarian adults as concerned with youth crimes and this is also the tendency among citizens in Eastern European countries (van de Vijver \& Leung, 2000). Adults were portrayed as contributing to the problems of young people in 15\% of the news items. Adults were advised by the media how to understand teenage children and how to help young people - looking positively to the youth, expressing their love and concern for young people, communicating with them, giving them support (including financial, medical, educational, and institutional one). Media tried to help young people and to improve their relationships with parents and institutions. We don't know from this study if giving advice in the media indeed works and to what extent it prevented violence, so this could be the object of further research.

This study reveals that violence is an important part of youth life being represented in Bulgarian media with a focus not only on reflecting cases of violence, but also emphasising how to prevent it, and not enough information is given about how to overcome the consequences of violence.

\section{References}

Aitken, S. C., \& Marchant, R. C. (2003). Memories and miscreants: Teenage tales of terror. Children's Geographics, 1 (1), 151-164. doi:10.1080/14733280302177

Allen, M. G. (1972). A cross-cultural study of aggression and crime. Journal of CrossCultural Psychology, 3(3), 259-271. doi:10.1177/002202217200300304

Anderson, C. A., Berkowitz, L., Donnerstein, E., Huesmann, L. R., Johnson, J. D., Linz, D., ... . \& Wartella, E. (2003). The influence of media violence on youth. Psychological Science in the Public Interest, 4(3), 81-110.

Anglin, L., Johnson, S., Giesbrecht, N., \& Greenfield, T. (2000). Alcohol policy content analysis: A comparison of public health and alcohol industry trade newsletters. Drug and Alcohol Review, 19, 203-212. doi:10.1080/713659313

Blumstein, A. (1995). Youth violence, guns, and the illicit-drug industry. The Journal of Criminal Law \& Criminology, 86, 10-36. doi:10.2307/1143998

Bolzan, N. (2003). "Kids are like that!" Community attitudes to young people. Retrieved from http://www.deewr.gov.au/Youth/Programs/NYARS/Documents/ bolzan_report.pdf 
Brady, S. S. (2007). Young adults' media use and attitudes toward interpersonal and institutional forms of aggression. Aggressive Behavior, 33, 519-525.

doi:10.1002/ab.20208

Children and violence. (1994, Winter). Behavioral Sciences \& the Law, 12(1), 1-3. doi:10.1002/bsl.2370120102

Clinton, W. J. (1999a). Letter to the Attorney General and the Chairman of the Federal Trade Commission on a study on youth violence and media marketing. Weekly Compilation of Presidential Documents, 6/7/99, 35 (22), 1011-1012.

Clinton, W. J. (1999b). Remarks announcing a study on youth violence and media marketing. Weekly Compilation of Presidential Documents, 6/7/99, 35 (22): 1009-1011.

Defrance, B. (1992). La violence à l'école. Paris: Syros-Alternatives.

Dohrn, B. (1997). Youth violence: False fears and hard truths. Educational Leadership, 55(2), 45-47.

Erwin, E. J., \& Morton, N. (2008). Exposure to media violence and young children with and without disabilities: Powerful opportunities for family-professional partnerships.

Early Childhood Education Journal, 36, 105-112. doi:10.1007/s10643-008-0276-x

Fanti, K. A., Vanman, E., Henrich, C. C., \& Avraamides, M. N. (2009). Desensitization to media violence over a short period of time. Aggressive Behavior, 35, 179-187. doi:10.1002/ab.20295

Martínez Ferrer, B., Moreno Ruiz, D., Amador, L. V., \& Orford, J. (2011). School victimization among adolescents. An analysis from an ecological perspective. Psychosocial Intervention, 20(2), 149-160. doi:10.5093/in201 1v20n2a3

Johnson, J. L. (2006). Cultural identity. Encyclopedia of Children, Adolescents, and the Media. Sage Publications. Retrieved March, 2009, from http://www.sageereference.com/childmedia/Article_n1 12.html

Kerezova, R. (2007). Заедно да кажем „Не" на насилието. [Together to say "No" to violence.] Public education, 47(4), 65-68.

Kim-Godwin, Y. S., Clements, C., McCuiston, A. M., \& Fox, J. A. (2009). Dating violence among high school students in Southeastern North Carolina. The Journal of School Nursing, 25(2), 141-151. doi:10.1177/1059840508330679 
Kivel, B. D., \& Johnson, C. W. (2009). Consuming media, making men: Using collective memory work to understand leisure and the construction of masculinity. Journal of Leisure Research, 41 (1), 109-133.

Kotria, B. (2007). Sex and violence: Is exposure to media content harmful to children? Children \& Libraries, 5(2), 50-52.

Kronenberger, W. G., Mathews, V. P., Dunn, D. W., Wang, Y., Wood, E. A., Larsen, J. J., .... \& Lurito, J. T. (2005). Media violence exposure in aggressive and control adolescents: Differences in self- and parent-reported exposure to violence on television and in video games. Aggressive Behavior, 31, 201-216. doi:10.1002/ab.20021

Lampman, C., Rolfe-Maloney, B., David, E. J., Yan, M., McDermott, N., Winters, S., ..., \& Lathrop, R. (2002). Messages about sex in the workplace: A content analysis of primetime television. Sexuality \& Culture, 6(4), 3-21. doi:10.1007/BF02719213

McGuire, W. (1986). The vicissitudes of attitudes and similar representational constructs in Twentieth century psychology. European Journal of Social Psychology, 16, 89-130. doi:10.1002/ejsp.2420160202

Meadow, R. G. (2009). Political violence and the media. Marquette Law Review, 93(1), 231-240.

Mills, M., \& Keddie, A. (2010). Cultural reductionism and the media: polarising discourses around schools, violence and masculinity in an age of terror. Oxford Review of Education, 36(4), 427-444. doi:10.1080/03054985.2010.494449

Moscovici, S., \& Markova, I. (2000). Ideas and their development: A dialogue between Serge Moscovici and Ivana Markova. In G. Duveen \& S. Moscovici (Eds.), Social Representations. Explorations in Social Psychology (pp. 224-286). Cambridge: Polity.

Moser, G. (1987). L'aggression. Paris: Presses universitaires de France.

Nesdale, D., \& Naito, M. (2005). Individualism-collectivism and the attitudes to school bullying of Japanese and Australian students. Journal of Cross-Cultural Psychology, 36(5), 537-556. doi:10.1177/0022022105278541

Olver, M. E., Stockdale, K. C., \& Wormith, J. S. (2009). Risk assessment with young offenders. A meta-analysis of three assessment measures. Criminal Justice and Behavior, 36(4), 329-353. doi:10.1177/0093854809331457 
Ramirez, J. M. (2007). Television y violencia. Revista Latinoamericana de Psicología, $39(2), 327-349$.

Redman, S., \& Taylor, J. (2006). Legitimate family violence as represented in the print media: textual analysis. Journal of Advanced Nursing, 56(2), 157-165.

doi:10.1111/j.1365-2648.2006.03996.x

Sadowski, M. J. (1993). As youth violence rages, many question media's role. School Library Journal, 39(9), 128-129.

Smorti, A., Menesini, E., \& Smith, P. K. (2003). Parents' definitions of children's bullying in a five-country comparison. Journal of Cross-Cultural Psychology, 34(4), 417-432. doi:10.1177/0022022103034004003

Stoyanova, S., Eylem, O., Veskioja, B., McDermott, E., Bozhilov, D., Slavov, S., \& Voetmann, K. (2010). Attitudes towards and social representations of young people. In: B. Slavchov \& E. Lazarova (Eds.), Social Cognition in Action (pp. 59-67). European Summer School "Social Cognition", 17th-24th July 2010, Blagoevgrad, Bulgaria.

Torregrosa, M. S., Ingles, C. J., \& Garcia-Fernandez, J. M. (2011). Aggressive behavior as a predictor of Self-concept: A study with a sample of Spanish compulsory secondary education students. Psychosocial Intervention, 20(2), 201-212. doi:10.5093/in201 1v20n2a8

Thys, P. (2003). Les conduits violentes: pourquoi et comment? In M. Comeron (Ed.), Jeunesse - Quartiers - Violence: pour une politique de prévention intégrée.. Manuel de Police, Supplément 67 (pp. 7-37).

van de Vijver, F. J. R., \& Leung, K. (2000). Methodological issues in psychological research on culture. Journal of Cross-Cultural Psychology, 31 (1), 33-51. doi:10.1177/0022022100031001004

van de Vliert, E., Schwartz, S. H., Huismans, S. E., Hofstede, G., \& Daan, S. (1999). Temperature, cultural masculinity, and domestic political violence: A cross-national study. Journal of Cross-Cultural Psychology, 30(3), 291-314.

doi:10.1177/0022022199030003002

Vidal, M. A., Clemente, M., \& Espinosa, P. (2003). Types of media violence and degree of acceptance in under-18s. Aggressive Behavior, 29, 381-392.

doi:10.1002/ab.10037 
Villarreal-González, M. E., Sánchez-Sosa, J. C., Veiga, F. H., \& Arroyo, G. M. (2011). Contextos de desarrollo, malestar psicológico, autoestima social y violencia escolar desde una perspectiva de género en adolescentes mexicanos. Psychosocial Intervention, 20(2), 171-181. doi:10.5093/in2011v20n2a5

Violence and the media: Influence on American youth. (1999, November). Congressional Digest, 78(11), 266-268.

Ward, J. (2005). An opportunity for engagement in cyberspace: Political youth web sites during the 2004 European Parliament Election Campaign. Information Polity, 10, 233-246.

Zimmerman, M. A., Morrel-Samuels, S., Wong, N., Tarver, D., Rabiah, D., \& White, S. (2004). Guns, gangs, and gossip - an analysis of student essays on youth violence. The Journal of Early Adolescence, 24(4), 385-41 1. doi:10.1 177/0272431604268551

Zlatanova, V. (2005). А^кохолизъм. [Alcoholism]. In G. Fotev (Ed.), Социология на Аевиантното поведение [Sociology of deviant behaviour] (pp. 330-353). Sofia: Prosveta, in Bulgarian.

Zografova, Y. (2001). Агресивността на българина в условията на прехол. [Bulgarian aggressiveness in the transitional period]. Sofia: Professor Marin Drinov Academic Publishing House, in Bulgarian.

About the author

Assoc. Prof. Stanislava Stoyanova, PhD, is a lecturer in Psychological measurements and Experimental Psychology at South-West University "Neofit Rilski". Her scientific interests are in the area of test development and test adaptation, and the study of social-psychological problems.

Stanislava Stoyanova, South-West University "Neofit Rilski", Bulgaria, 66, Ivan Mihailov Street, 2700 Blagoevgrad, Bulgaria, avka@swu.bg 


\section{Appendix}

2.1. Newspaper:

2.2. Date:

3. 1. Number of paragraphs
2.3. Vol. /issue

3.2.Page/s

- Last page

- All other pages

3.3. Number of photos/illustrations

6. Focus of article (Tick as many as appropriate)

\begin{tabular}{|c|c|c|c|c|}
\hline Family issues & Medical & Advertising & Health/Diets & Driving \\
\hline Politics & $\begin{array}{l}\text { Culture } \\
\text { Music, art, } \\
\text { etc.) }\end{array}$ & $\begin{array}{l}\text { Showbiz/ } \\
\text { Entertainment }\end{array}$ & Law and Order & $\begin{array}{l}\text { Academy/ } \\
\text { education }\end{array}$ \\
\hline Religion & Business & Welfare & Sexual & Victims \\
\hline Deviant behaviour & $\begin{array}{l}\text { Alcohol/Drug } \\
\text { use }\end{array}$ & Employment & $\begin{array}{l}\text { Prevention/ } \\
\text { Giving advice }\end{array}$ & $\begin{array}{l}\text { Scientific/ } \\
\text { Technological }\end{array}$ \\
\hline Sport & Other & & & Not applicable \\
\hline
\end{tabular}

9. Sources' and this media's attitude towards young people. Code for the whole news item.

\begin{tabular}{|l|l|l|}
\hline None/neutral & More positive than negative & Only negative \\
\hline Only positive & More negative than positive & \\
\hline
\end{tabular}


12. Labels that sources and this media use when referring to young people

\begin{tabular}{|l|l|l|l|l|}
\hline Ethnic belonging & No labels & \multicolumn{2}{|l|}{} \\
\hline Religious belonging ..................................... & Citizens & $\begin{array}{l}\text { Gender belonging } \\
\text {......................... }\end{array}$ & Deviants & Victims \\
\hline Violent & Residents & Unemployed & Hooligans & Customers \\
\hline Minorities & $\begin{array}{l}\text { Out of } \\
\text { control }\end{array}$ & Foreigners & Criminals & Rebels \\
\hline Poor persons/families & Neighbours & Youth gangs & Protesters & Immigrants \\
\hline Insert labels & & & & \\
\hline & & & & \\
\hline & & & & \\
\hline
\end{tabular}

13. Adults' positions towards young people reflected by the chosen media

\begin{tabular}{|l|}
\hline dysfunctional homes causing young people to have problems \\
\hline schools not preparing students \\
\hline adults were advised how to understand teenage children \\
\hline adults should punish young people \\
\hline society doesn't offer many job opportunities for young people \\
\hline young people need prevention \\
\hline ..................... \\
\hline
\end{tabular}


14. Important themes: Indicate the presented themes by X. Selected quotations illustrating type of material coded.

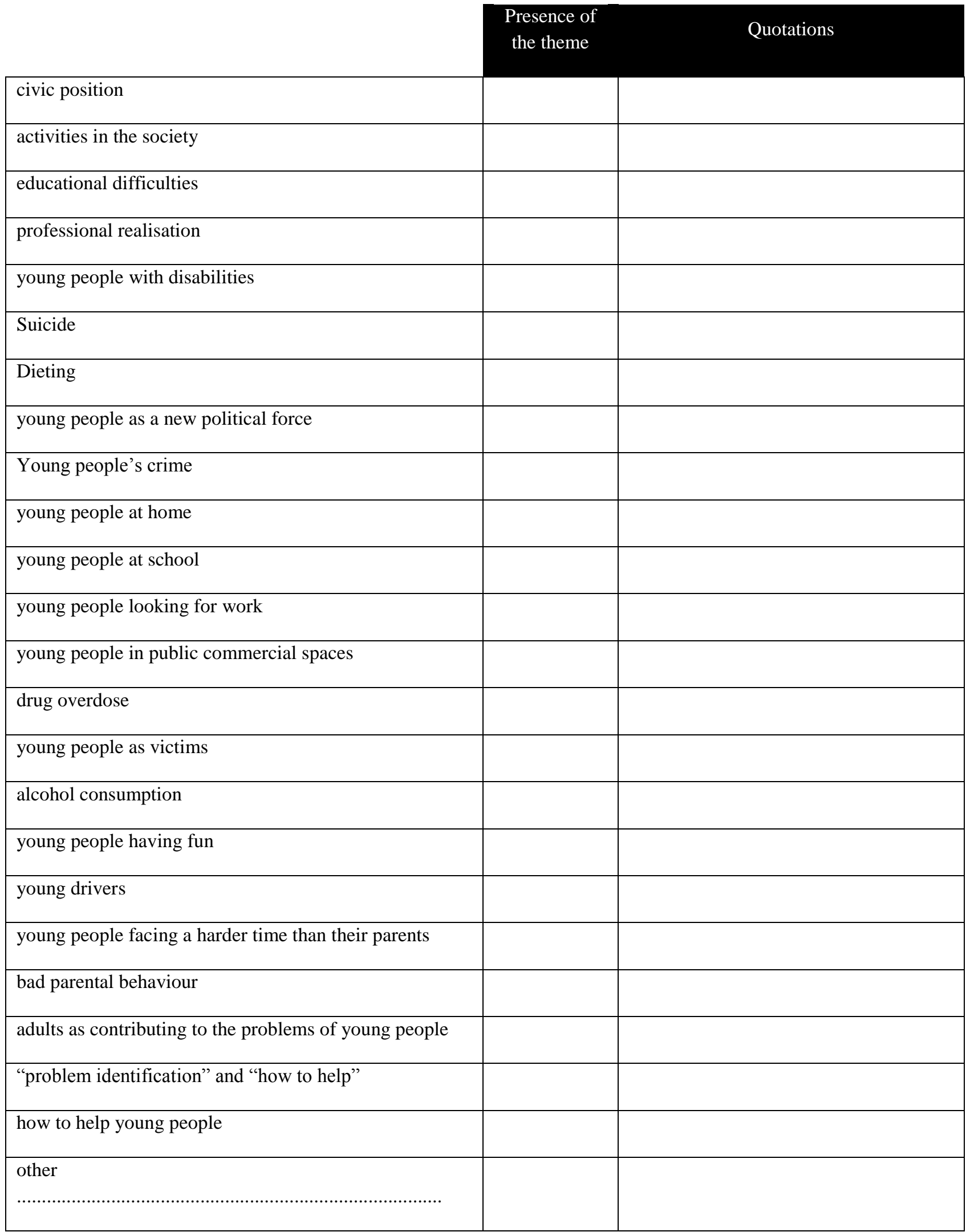

15. Media giving advice to: Indicate the presented themes by X. Selected quotations illustrating type of material coded.

- None/Not applicable 
- Parents

- $\quad$ Young people

- The whole society

- Other

Quotation: “. 